\title{
Poteškoće i dobrobiti rada s osobama oboljelim od demencije iz perspektive formalnih njegovatelja
}

\author{
ANA ŠTAMBUK* \\ Studijski centar socijalnog rada \\ Pravni fakultet Sveučilišta u Zagrebu \\ Zagreb, Hrvatska
}

\author{
Izvorni znanstveni rad \\ UDK: 364.62 \\ doi: $10.3935 /$ rsp.v25i2.1442 \\ Primljeno: veljača 2017.
}

\section{KRISTINA LEVAK}

Nemogućnost samostalne brige o sebi često je u starijoj dobi uzrokovana djelovanjem raznih bolesti. Skrb za osobu oboljelu od demencije opisana je kao najzahtjevniji oblik skrbi zbog intenzivne i dugotrajne njege. S obzirom na to da trenutno oko 47 milijuna ljudi boluje od ove bolesti, čija se ekspanzija tek očekuje, može se reći da ima velik ekonomski značaj za društvo. Moderne obitelji, uslijed zahtjeva svakodnevnog života, više nisu u mogućnosti adekvatno brinuti o svojim članovima, zbog čega je povećana potreba za formalnim oblicima skrbi. Profesionalni, odnosno formalni njegovatelji su stručnjaci različitih profesija koji se svakodnevno suočavaju s mnogim izazovima skrbničkog odnosa. Cilj ovog istraživanja bio je dobiti uvid u poteškoće $i$ dobrobiti rada s osobama oboljelim od demencije iz perspektive formalnih njegovatelja. U kvalitativnom istraživanju sudjelovalo je 15 njegovatelja iz 4 različite institucije na području grada Zagreba s kojima su provedeni polustrukturirani intervjui. Rezultati tematske analize podataka pokazali su da njegovatelji kao probleme u radu prepoznaju nerazumijevanje od strane članova obitelji te organizaciju rada. Osim toga, skrb ih dovodi do iscrpljenosti i osjećaja bespomoćnosti. Kada govorimo o dobrobitima rada, rezultati pokazuju da osim emocionalnog ispunjenja i povećanog osjećaja smisla $i$ životne svrhe, njegovatelji dobrobitima percipiraju i osobni rast te stečeni novi pogled na osobe starije životne dobi. Zaključno, istraživanje pokazuje da su potrebna daljnja sustavna istraživanja o njegovateljima, kako bi se dobile smjernice za razvijanje sustava koji se za Hrvatsku može okarakterizirati prilično nedostatnim s obzirom na postojeće potrebe.

Ključne riječi: starije osobe, formalni njegovatelji, demencija, skrb.

* Ana Štambuk, Studijski centar socijalnog rada, Pravni fakultet Sveučilišta u Zagrebu / Department of Social Work, Faculty of Law, University of Zagreb, Nazorova 51, 10000 Zagreb, Hrvatska / Croatia, ana.stambuk@ pravo.hr 


\section{UVOD}

Trend starenja stanovništva nametnuo je društvu važnost skrbi o starijim osobama. Tradicionalni oblici skrbi, gdje mlađe generacije brinu o ostarjelim roditeljima u obiteljskom okruženju, sve više ustupaju mjesto formalnim oblicima skrbi. Nemogućnost samostalne brige o sebi često je uzrokovana djelovanjem raznih bolesti koje zahvaćaju stariju populaciju. Uzevši u obzir da je prema popisu iz 2011. godine, udio stanovništva starijeg od 65 godina čak 17,7\% (Državni zavod za statistiku, 2016.) Hrvatska se svrstava među zemlje s najstarijim stanovništvom (Jedvaj i sur., 2014.), a upravo je ta populacija najviše zahvaćena demencijom. Demencija je bolest koja iziskuje intenzivnu i dugotrajnu skrb, koju često obitelj bez podrške resursa zajednice nije u stanju pružiti. Formalnu skrb pružaju stručnjaci različitih profila (medicinske sestre, njegovatelji, fizioterapeuti, socijalni radnici itd.). Osim rada s velikim brojem korisnika, rada u multidisciplinarnom timu i sa članovima obitelji oboljelih, njegovatelji trebaju imati vještine i znanja kako bi se mogli profesionalno odnositi prema promjenama u ponašanju oboljelih nastalih uslijed progresije bolesti. Sve navedeno ukazuje na visoke zahtjeve skrbi zbog čega raste istraživački interes za izazove $\mathrm{s}$ kojima se formalni njegovatelji suočavaju. Tema demencije predmet je bogate strane literature, međutim hrvatska istraživanja vezana uz formalne njegovatelje oskudna su te većim dijelom pisana iz medicinske perspektive. Milić Babić i sur. (2014.) ukazuju na važnost sustavnih akcijskih i kvalitativnih istraživanja vezanih uz njegovatelje koja bi mogla biti temelj unaprjeđenju pružanja podrške istima. U skladu s mišljenjem različitih autora i njihovim implikacijama za budući istraživački rad, u ovom smo se istraživanju usmjerili na izazove s kojima se profesionalni, odnosno formalni njegovatelji susreću u radu s osobama oboljelima od demencije. Kvalitativnim pristupom nastojalo se dobiti uvid u osobni doživljaj pružanja njegovateljske skrbi i doprinijeti dubljem razumijevanju ovog fenomena. Rezultati istraživanja mogli bi poslužiti, kao što predlaže Mimica (2011.), i »za stvaranje akcijskog plana« u borbi s nadolazećom epidemijom u skorijoj budućnosti. U uvodnom dijelu rada definirat ćemo ključne pojmove i prikazati dosadašnje spoznaje, a kroz rezultate i raspravu dati uvid u izazove skrbi (poteškoće i dobrobiti) s kojima se susreću formalni njegovatelji. U završnom dijelu rada upućuje se na ključne rezultate i ograničenja provedenog istraživanja popraćena implikacijama za budući rad istraživača.

\section{Definiranje pojmova i trendovi u pojavnosti demencije}

Demencija se definira kao klinički sindrom uzrokovan bolešću mozga, kroničnog ili progresivnog tijeka sa stečenim višestrukim oštećenjem pamćenja, mišljenja, shvaćanja, rasuđivanja, orijentacije, sposobnosti učenja, jezika i računanja (FolnegovićŠmalc i sur., 2002.). Oko dvije trećine svih demencija uzrokovano je Alzheimerovom bolesti. Budući da bolest nema kauzalnog farmakološkog liječenja, liječenje se ponajviše temelji na suportivnoj terapiji (Kovačić Petrović i Repovečki, 2016.). Skrb za oboljele odnosi se na pomoć u smislu povećanja kvalitete života i odgodu progresije bolesti. Broj oboljelih od demencije u suvremenim zemljama je u stalnom porastu. O ekonomskom značaju bolesti dovoljno govori procjena kako diljem svijeta trenutno više od 47 milijuna ljudi boluje od demencije (Alzheimer's Disease International, 2015). Mimica (2011.) očekuje kako će ta brojka drastično rasti te će do 2050. 
godine biti učetverostručena zbog čega apelira na mobiliziranje resursa kako bi se naše društvo moglo suočiti s nadolazećim problemima. Brodaty i Donkin (2009.) iznose podatak da se svake godine u svijetu bilježi 4,6 milijuna novih slučajeva, što je, slikovito prikazano, cijela jedna Hrvatska. Milić Babić i sur. (2014.) upozoravaju kako zdravstveni i financijski sustavi zemalja nisu pripremljeni na ovu epidemiju. Broj oboljelih u Hrvatskoj Mimica i Presečki (2010.) procjenjuju na približno $80000 \mathrm{i}$ ukazuju na veliku neproporcionalnost u odnosu na broj stručnjaka koji istima pružaju formalnu skrb. Različiti autori (Schoenmakers i sur., 2010.; Droes i sur., 2004.) ističu da njegovatelji oboljelih od demencije pokazuju veći osjećaj tereta od njegovatelja osoba s fizičkim poteškoćama, odnosno $\mathrm{s}$ drugim kroničnim bolestima. Problemi su vezani za prepoznavanje bolesti koje je, zbog nedovoljne senzibilizacije javnosti kao i nedovoljne edukacije stručnjaka koji rade $\mathrm{s}$ ovom populacijom, veoma otežano (Milić Babić i sur., 2014.). Rusac i sur. (2012.) upozoravaju kako neprepoznata ozbiljnost i epidemiologija problema te nepostojanje registra, onemogućava dobivanje prave slike o razmjeru ovog problema. Progresivna narav bolesti upućuje na potrebu prilagođavanja skrbi sukladno razvojnoj fazi u kojoj se bolesnik nalazi, koja je u početku teža za oboljelog, a kasnije veći teret snose članovi obitelji (odnosno neformalni njegovatelji), ali i formalni njegovatelji (plaćeni profesionalci koji rade $u$ ustanovama gdje se pruža skrb oboljelima od demencije). Navedeno potvrđuje tezu da od Alzheimerove bolesti »ne obolijeva samo pojedinac već čitava obitelj« (Poredoš, 2003.). Početna skrb obično se pruža u okviru obiteljskih resursa, no s napretkom bolesti potreba za formalnim oblicima skrbi postaje sve značajnija.

\section{Utjecaj skrbi na formalne njegovatelje}

Pojam deinstitucionalizacije sve se češće spominje u kontekstu brige o starijim osobama te postaje cilj različitih mjera i politika. Ipak, jedan dio starijih osoba zbog izrazito lošeg zdravstvenog stanja treba skrb u specijaliziranim institucijama za njegu (u bolnicama ili domovima za starije). Neminovni problem koji se javlja vezano uz formalne oblike skrbi jest upravo njihova nedostatnost i u velikim gradovima, dok su ruralne sredine $u$ još nepovoljnijem položaju. Također, današnji korisnici smješteni u institucije, zbog uglavnom teškog zdravstvenog stanja, trebaju specijaliziranu $\mathrm{i}$ intenzivnu njegu. Istraživanje koje su provele Štambuk i sur. (2014.) pokazuje da je uloga socijalnog radnika u ustanovama za starije i nemoćne osobe vrlo složena i uključuje individualni, grupni, obiteljski i timski rad te da je potrebna specifična edukacija iz područja palijativne skrbi i psihoorganskih bolesti. Parker i Penhale (1998.) ističu kako briga o oboljelima od demencije zahtijeva cjelovit multidisciplinaran pristup koji treba biti temeljen na kompetentnoj i učinkovitoj praksi uz visoke profesionalne vještine. Stoga smo u ovo istraživanje uključile formalne njegovatelje, odnosno profesionalce različitih područja kako bi se mogla dobiti sveobuhvatna slika poteškoća i dobrobiti rada s osobama oboljelima od demencije. Formalni njegovatelji su plaćeni pojedinci zaposleni u agencijama ili organizacijama koje pružaju usluge skrbi kao što su domovi za starije osobe i zdravstvene organizacije (Colello, 2009.).

Istraživački interes vezan uz ovu temu češće je bio usmjeravan na obiteljske (neformalne) njegovatelje. Rusac i sur. (2012.) $\mathrm{u}$ istraživanju dolaze do rezultata kako su njegovatelji visoko opterećeni zahtjevima dnevne skrbi. S druge strane, druga istra- 
živanja (Brodaty i Donkin, 2009.) upućuju i na motivacijske čimbenike koji olakšavaju skrb obiteljskim njegovateljima: ljubav prema oboljeloj osobi, duševna ispunjenost te osjećaj dužnosti. Formalni njegovatelji su educiraniji i kompetentniji za pružanje skrbi, no kod njih izostaju motivacijski čimbenici vezani uz rodbinski odnos $\mathrm{s}$ oboljelima. Kovačić Petrović i Repovečki (2016.) utvrdili su kako veću učestalost anksioznih i depresivnih simptoma pokazuju obiteljski njegovatelji, dok su za profesionalne njegovatelje uočili da duljina staža utječe na veću učestalost negativnih simptoma. Upravo bi zbog toga bilo vrijedno otkriti što je to što, unatoč visokim zahtjevima profesionalnog njegovanja osoba oboljelih od demencije, motivira formalne njegovatelje da ustraju raditi taj posao sa zadovoljstvom. Herzberg je u svojoj teoriji motivacije i higijene govorio o faktorima značajnim za zadovoljstvo poslom i naglašavao važnost isticanja onih karakteristika posla koje zaposlenici smatraju korisnim (Robbins, 1992.). Brojni autori su ulogu njegovatelja dovodili u vezu s različitim obilježjima. Religioznost se pokazala kao jedan od važnih faktora koji utječu na percepciju bolesti od strane njegovatelja (Levkoff i sur., 1999.). Perko i sur. (2005.) ističu važnost trajne edukacije stručnjaka kako bi se konstruktivno suočavali sa zahtjevima skrbi. Hayajneh i Shehadeh (2014.) spominju da je poznavanje prijašnjeg života oboljele osobe veoma bitno kroz tzv. pristup usmjeren na osobu i naglašavaju kako se njime omogućava drukčiji doživljaj skrbničkog odnosa. Zadelhoff i sur. (2011.) opisuju iskustva rada s oboljelima s obzirom na vrstu ustanove u kojoj stručnjaci rade. Zaključuju da zajedničko stanovanje (eng. group living homes) omogućava njegovateljima da ostvare bliski odnos s oboljelima što utječe i na doživljaj rada njegovatelja. Konačno, kako bi se u budućnosti unapri- jedila skrb za oboljele te osigurala podrška njegovateljima, važno je poznavati izazove rada iz njihove perspektive.

\section{CILJ I ISTRAŽIVAČKA PITANJA}

Cilj ovog istraživanja bio je dobiti uvid $\mathrm{u}$ izazove rada s osobama oboljelim od demencije iz perspektive formalnih njegovatelja.

Sukladno cilju istraživanja postavljena su dva istraživačka pitanja:

1. Koji su problemi s kojima se formalni njegovatelji suočavaju kroz skrb za osobe oboljele od demencije?

2. Koje dobrobiti rada s osobama oboljelim od demencije prepoznaju formalni njegovatelji?

\section{METODA}

\section{Uzorak}

Sudionici istraživanja su stručnjaci (formalni njegovatelji) trenutno zaposleni u ustanovama koje pružaju skrb za osobe oboljele od demencije na području grada Zagreba. Istraživanje je provedeno na uzorku od 15 ispitanika iz četiri ustanove, gdje je samo jedan ispitanik bio muškog spola. Radi se o ustanovama koje pružaju različite oblike skrbi: dnevni boravak u sklopu gerontološkog centra, cjelodnevni boravak za osobe oboljele od demencije, privatni dom te dom za starije i nemoćne s odjelom za skrb o osobama oboljelim od demencije. Do ispitanika se došlo tako da je kontaktiran socijalni radnik iz ustanove te je on dao preporuku koji bi od njegovih kolega bili potencijalni ispitanici, pri čemu je jedini kriterij bio da sudjeluju u neposrednom radu s oboljelima. Iako je prethodno postojala ideja o dodatnim kriterijima (jednaka zastupljenost različitih struka, godine iskustva rada itd.), od istoga se odustalo jer 
bi zbog malog broja ukupno zaposlenih na tom području bilo nemoguće napraviti bilo kakvo istraživanje.

Prosječna dob ispitanika je 36 godina, pri čemu najmlađi ispitanik ima 20, a najstariji 60 godina. Radi se o stručnjacima sa srednjom ili višom stručnom spremom, po zanimanju su to medicinske sestre, radne terapeutkinje, fizioterapeutkinje te njegovatelj(ice). Dio njih prošao je edukaciju za rad s oboljelima od demencije. Duljina staža ispitanika u skrbi za osobe s demencijom varira od 6 mjeseci pa do 30 godina (prosjek 5,5 godina). Glede toga, uočen je nedostatak istraživanja jer dio ispitanika radi s oboljelima od demencije manje od godine dana, što je uzrokovalo puno sažetijim opisima iskustava rada. Ispitanici cijelo radno vrijeme (8 sati) provode u neposrednom radu s oboljelima.

\section{Postupak}

Istraživanje je provedeno tijekom lipnja i srpnja 2016. godine u ustanovama u kojima formalni njegovatelji rade. Najprije su telefonski kontaktirane socijalne radnice koje su procijenile tko od djelatnika ima najviše iskustva u radu na ovom području te su iste osobe upitane za sudjelovanje. Svih 15 predloženih formalnih njegovatelja dobrovoljno je pristalo sudjelovati $u$ istraživanju, što je bilo dovoljno da dođe do teorijskog zasićenja. Podaci su prikupljeni primjenom polustrukturiranog intervjua. Prethodno je osmišljen predložak za intervju koji je sadržavao 10 glavnih te 5 dodatnih pitanja. Po završetku svakog intervjua, zatražili su se dodatni sociodemografski podaci (dob, zanimanje, duljina radnog iskustva na područja skrbi za oboljele od demencije). Prosjek trajanja intervjua bio je 25 minuta.

Prije prikupljanja podataka pribavljena je suglasnost o provedbi istraživanja od strane Gradskog ureda za socijalnu zaštitu $\mathrm{i}$ osobe s invaliditetom. Tijekom provedbe istraživanja poštovana su različita etička načela. Svi ispitanici upoznati su s ciljem i svrhom istraživanja. Anonimnost je osigurana tako da se u objavi rezultata ne spominju osobni podaci, već se pojedinog ispitanika prikazuje pomoću oznake »ISP« (ispitanik) i broj koji mu je dodijeljen sukladno redoslijedu provođenja intervjua. Nigdje $\mathrm{u}$ tekstu se ne spominju nazivi ustanova $\mathrm{u}$ kojima je istraživanje provedeno, kako se odgovori ispitanika ne bi mogli dovesti u vezu s pojedinim djelatnicima.

Ispitanici su bili upoznati s mogućnošću prekida sudjelovanja kao i sa snimanjem razgovora diktafonom za što su dali usmeni pristanak. Obaviješteni su i o daljnjem postupanju s prikupljenom empirijskom građom (uništavanje intervjua $\mathrm{u}$ roku od godine dana, pridavanje identifikacijskih oznaka prilikom kodiranja i prikaza rezultata). Također im je ostavljena mogućnost dobivanja uvida u rezultate istraživanja.

\section{Obrada podataka}

Korištena metoda obrade podataka u literaturi se pojavljuje pod nazivom tematska analiza podataka (Braun i Clarke, 2006.). Ista se metoda smatrala najprikladnijom $\mathrm{s}$ obzirom na temu i njoj pripadajuća istraživačka pitanja. Induktivnim se pristupom (Elo i Kyngas, 2007.) omogućilo produbljivanje teme izazova i na područja koja se ne bi mogla unaprijed predvidjeti iz literature. Obrada podataka nakon izrade transkripta uključivala je: čitanje transkripta i bilježenje onih dijelova koji predstavljaju odgovor na odabrana istraživačka pitanja $\rightarrow$ traženje zajedničkih tema koje proizlaze iz sličnosti sadržaja i pripisivanje kodova tim temama $\rightarrow$ grupiranje sadržajno sličnih tema i definiranje istih $\rightarrow$ provjera odgovaraju li kodovi i teme istraživačkim 
pitanjima $\rightarrow$ izrada tematske mape (Braun i Clarke, 2006.). Osim toga, odgovori koji su uočeni kao vidno drukčiji od ostalih, tzv. odstupajući slučajevi, bit će spomenuti u raspravi budući da i oni predstavljaju odgovore ispitanika.

\section{REZULTATI I RASPRAVA}

Rezultati istraživanja prikazani su kroz dva tematska područja: 1) problemi, odnosno poteškoće formalnih njegovatelja u skrbi za oboljele od demencije; 2) dobrobiti rada s osobama oboljelim od demencije.
Za svako su tematsko područje označene specifične teme, opisane pomoću podtema koje su u daljnjem tekstu upotpunjene izjavama ispitanika.

Problemi formalnih njegovatelja u skrbi za oboljele od demencije

Prvo tematsko područje prikazano je kroz četiri teme koje predstavljaju odgovor na prvo istraživačko pitanje. U svrhu preglednijeg prikaza sve su teme i podteme prikazane u Tablici 1 .

Tablica 1.

Problemi formalnih njegovatelja u skrbi za oboljele od demencije

\begin{tabular}{|c|c|}
\hline \multicolumn{2}{|c|}{ Tematsko područje: Problemi formalnih njegovatelja u skrbi za oboljele od demencije } \\
\hline Teme & Podteme \\
\hline Nerazumijevanje od članova obitelji & $\begin{array}{l}\text { 1. Slaba educiranost članova obitelji o bolesti } \\
\text { 2. Neprihvaćanje bolesti od strane članova obitelji } \\
\text { 3. Nerealni zahtjevi članova obitelji od stručnih } \\
\text { djelatnika } \\
\text { 4. Teško prilagođavanje obitelji na progresiju bolesti } \\
\text { 5. Nepovjerenje prema stručnim djelatnicima }\end{array}$ \\
\hline Organizacija rada & $\begin{array}{l}\text { 1. Manjak osoblja } \\
\text { 2. Zahtjevnost rada u noćnim smjenama } \\
\text { 3. Nemogućnost individualiziranog pristupa oboljelima }\end{array}$ \\
\hline 3. Iscrpljenost & $\begin{array}{l}\text { 1. Fizički napor } \\
\text { 2. Psihička iscrpljenost } \\
\text { 3. Narušeno tjelesno zdravlje }\end{array}$ \\
\hline 4. Osjećaj bespomoćnosti & $\begin{array}{l}\text { 1. Teškoće u prepoznavanju potreba oboljelih } \\
\text { 2. Smanjeno osobno postignuće } \\
\text { 3. Teška i nerazumljiva ponašanja korisnika } \\
\text { 4. Nužnost uzimanja lijekova za smirenje }\end{array}$ \\
\hline
\end{tabular}

1. Nerazumijevanje od članova obitelji prepoznato je kao problem, do kojeg dovodi, kako ističu njegovatelji: slaba educiranost članova obitelji o bolesti, neprihvaćanje bolesti od strane članova obitelji, nerealni zahtjevi članova obitelji od stručnih djelatnika, teško prilagođavanje obitelji na progresiju bolesti te nepovjerenje prema stručnim djelatnicima.

O slaboj educiranosti članova obitelji o bolesti njegovatelji govore u sljedećim izjavama: »...u biti bi njima trebalo neko predavanje, edukacija, da znaju šta je to, oni misle 'gle moja mama je normalna, a 
tu je zatvorena'... ne znaju dovoljno o bolesti..." (ISP7); "Mislim da bi trebalo više educirati obitelji, da se rade nekakva predavanja, da se jednostavno malo ljudima to približi ..." (ISP2); "... treba poraditi na edukaciji obitelji jer je to jako slabo..." (ISP6). Poredoš (2003.) je isticala važnost edukacije za članove obitelji kojima su osim edukacije potrebni i savjeti i konkretne akcije. Puljak i sur. (2005.) upozoravali su da će s obzirom na tendenciju porasta bolesti, educiranje postati nužnost. Međutim, gledajući zapažanja formalnih njegovatelja u ovom istraživanju, desetak godina kasnije, ovaj je problem i dalje izražen. Štambuk i sur. (2014.) u istraživanju provedenom sa socijalnim radnicama zaposlenima u domovima za starije i nemoćne, dolaze do rezultata da su i njima potrebne edukacije iz područja psihoorganskih bolesti kod starijih osoba, pa i demencije. Po pitanju edukacije formalnih njegovatelja ipak se uočava određeni pomak budući da su sudionici ovog istraživanja često spominjali veliku korisnost edukacija koje su oni prolazili, a naglašavali su nedostatnost istih samo za članove obitelji oboljelih.

Nedostatak edukacije i podrške članovima obitelji oboljelih na neki način objašnjava neprihvaćanje bolesti od strane članova obitelji što se također navodi kao jedan od segmenata koji vode k nerazumijevanju od strane članova obitelji. »Njima je teško prihvatiti da, recimo, roditelj njih ne prepoznaje ili da roditelj napravi nešto što bi stvarno napravilo malo dijete; ali, moj tata, moja mama, to je nemoguće..." (ISP5); "...Jednostavno ne može prihvatit samu tu dijagnozu svoje majke i onda su svi krivi, umjesto da prihvati i suoči se..." (ISP7); "Članovi obitelji vrlo teško prihvaćaju da je njihova bliska osoba oboljela od te bolesti, jer zaboravljaju ... Znači na kraju bolesti vjerojatno ih više neće ni prepoznati i to je jako teško prihvatiti, ja to shva- ćam .... Treba im potvrdit to da im je teško, tu je veliki problem šta se obitelji tiče..." (ISP10). Diminić-Lisica i Rončević-Gržeta (2010.) govore općenito o prihvaćanju kroničnih bolesti u obitelji. Isti ističu kako članovi obitelji nerijetko negiraju bolest. Događa se, npr. u slučaju demencije, da je obitelj svjesna bolesti, ali teško prihvaća da osoba koju su do tad poznavali počinje imati potpuno regresivna i za nju neuobičajena ponašanja.

Članovi obitelji često postavljaju nerealne zahtjeve od stručnih djelatnika: "... mi smo ko na traci, a oni dođu i onda misle kako mi valjda ništa ne radimo i tako, zahtijevaju nešto što mi jednostavno ne možemo..." (ISP7); "...mislim da su neki onako malo više zahtjevni, a neki imaju više razumijevanja prema nama, neki očekuju svašta. Neki se nisu pomirili s tim da su njihovi članovi oboljeli od Alzheimera pa očekuju od nas da će ozdravit ili tako nešto..." (ISP9); »Ima nekih koji zahtijevaju nešto što recimo uopće ne ovisi o nama, tipa terapije, a mi to ne određujemo..." (ISP12). $\mathrm{O}$ nerealnim zahtjevima članova obitelji govore Mitrani i Czaja (2000.) koji ističu kako je uloga stručnjaka pronaći balans između pružanja podrške članovima obitelji i postavljanja ograničenja nerealnim zahtjevima. Socijalne radnice zaposlene u domovima za starije i nemoćne, u istraživanju Štambuk i sur. (2014.) također su navodile kako obitelj često krivo percipira i njihovu ulogu nakon smještaja u dom, što stručnim djelatnicima predstavlja velik izazov u radu. S jedne strane, treba razumjeti obitelj i uvažavati činjenicu da se teško nose $\mathrm{s}$ bolesti, a s druge strane znati kako pojasniti obitelji vlastitu profesionalnu ulogu (posebno istaknuti ograničenja). Stoga bi u edukaciji članova obitelji svakako bilo korisno da i njegovatelji budu uključeni te jasno kažu koji su njihovi poslovi, kako se članovi obitelji mogu uključiti i sl. 
Iako se obitelj na početku bolesti dobro nosi s novonastalom situacijom, u nekim slučajevima dolazi do teške prilagodbe obitelji na progresiju bolesti: "... s vremenom je ponašanje sve teže $i$ teže... a obitelj misli da oni još puno stvari mogu kao što su mogli na početku bolesti...kao da ne prihvaćaju da je bolest progresivna, nekad se to jako brzo mijenja..." (ISP5); "... s godinama demencija napreduje, recimo unazad šest mjeseci kod njih se stanje jako promijenilo, a obitelj misli da su kao prije..." (ISP 15). Pojava bolesti počinje narušavati kvalitetu života oboljele osobe, a njezina progresivnost kasnije se jače odražava na osobe koje skrbe o oboljelome zbog čega Poredoš (2003.) zaključuje da kad bolest okupira osobu, veći teret snose članovi obitelji.

Formalni njegovatelji nadalje uočavaju i da obitelj nema povjerenja prema stručnim djelatnicima: »... baš nekad propituju svaku stvar, zašto ste ovako zašto onako, trebali bi drukčije to raditi, ...kao da uopće nemaju povjerenja da mi radimo najbolje šta možemo za njihove roditelje..." (ISP14); "...A ta obitelj uredno dođe i uredno napada, ... kćer se uporno buni kako su njenu mamu opljačkali... mi pokušavamo objasnit, približit to, al ne, ona uporno misli da mi muljamo..." (ISP7); »... a i najteže je u početku dok obitelj malo ne stekne povjerenje u vas, jer baš znaju sve kontrolirat i provjeravat što smo i kako napravili..." (ISP9); "...znate ono nitko ne vjeruje kako je nama..." (ISP7). Izostanak povjerenja u stručne djelatnike dodatno otežava međusobnu suradnju. Od neprocjenjive je važnosti kad obitelj korisnika vjeruje da je sve što stručnjaci rade u cilju dobrobiti za njihovog člana obitelji (Štambuk i sur., 2014.). Često je obitelj prije smještaja u ustanovu skrbila o oboljeloj osobi. Iako im formalna pomoć može značajno olakšati skrb, Schoenma- kers i sur. (2010.) navode kako često članovi obitelji postaju zabrinuti za kvalitetu pružene njege. Drugi autori ističu važnost uključivanja članova obitelji u skrb za oboljelog kao i permanentnu informiranost o stanju oboljelog te da to bude izvedeno s pažnjom, strpljenjem i empatijom (Li, 2002.; Naylor i sur., 2005.; Nichols, 2006). Stvaranje sustava kvalitetne podrške članovima obitelji između ostalog znači i izgradnju odnosa povjerenja kroz uključivanje obitelji u odluke kako bi se zajedno pronašla najbolja rješenja (Laklija i sur., 2009.). Pri tome oni zajedno stvaraju i osmišljavaju plan skrbi za oboljelu osobu što članove obitelji čini aktivnim sudionicima (a ne pasivnim i nemoćnim promatračima).

2. Problem organizacije rada proizlazi iz nekoliko obilježja: manjak osoblja, zahtjevnost rada u noćnim smjenama te nemogućnost individualiziranog pristupa (Slika 1.)

\section{Slika 1.}

Prikaz povezanosti problema u organizaciji rada s oboljelima od demencije

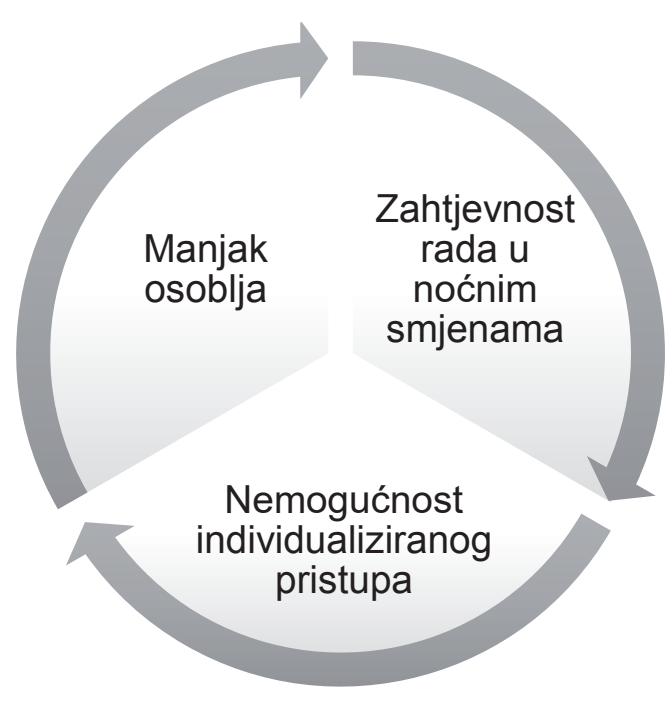


Prvo što njegovatelji spominju je manjak osoblja: "... mi ne stignemo obaviti puno toga... kad jedna osoba ostane poslije podne sama na katu, podijeliš lijekove ... ima nas premalo i taman ono jedno za drugim obaviš..." (ISP7); "...ustvari, ja ni nemam pauze, nema me tko zamijenit jer nas je premalo, nego ono trčeći jedem i tako da ni nema pauze da ja sad mogu reći evo imam pol sata pauze da se ja isključim...nema šanse. Kad jedem, dođe mi za stol pa se sjedne skupa sa mnom, pa mi uzima iz tanjura..." (ISP3); "...nemamo dovoljno osoblja za to..." (ISP6); »Nema dosta ni kadra, to je pod broj jedan i to je osnovno, jako malo je tog stručnog osoblja $i$ jednostavno ne mogu ni stići sve...evo meni je ovdje isto kaos..." (ISP1). Kvalitetan rad neminovno iziskuje dovoljan broj zaposlenih stručnjaka različitog profila. Iz odgovora se može vidjeti kako su sami formalni njegovatelji svjesni da ne mogu pružiti adekvatnu skrb budući da većinu vremena provode na zadovoljavanje osnovnih potreba velikom broju korisnika. Podatak o manjku osoblja nije veliko iznenađenje s obzirom na to da su i druga istraživanja kod drugih populacija došla do sličnih problema (Štambuk i sur., 2014.). Ono što je nužno napomenuti su uočene razlike između ispitanika ovisno o ustanovama u kojima rade. Naime, njegovatelji koji rade samo na specijaliziranom odjelu za oboljele od demencije pokazuju puno manji problem nedostatka vremena i osoblja za razliku od onih koji svoj posao obavljaju na nekoliko odjela. Ističu i bolju suradnju s članovima obitelji: »Razgovorom se sve dogovorimo, imamo dosta prostora tu jer taj odjel nije baš tako nešto posebno dinamičan pa imamo dosta prostora s njima sjesti i razgovarati... kako bi trebalo $i$ biti.« (ISP14). S obzirom na to da su takvi odjeli relativno novi u Hrvatskoj i da je trenutno u planu otvaranje novih, možemo se nadati da u budućim istraživanjima ovakve izjave neće biti odstupajuće.

Sljedeći uočeni problem je zahtjevnost rada u noćnim smjenama: »...nije lako jer ovdje su noćne 'krvave', znate kako stari ljudi, po danu spavaju, a po noći svi 'idu doma', i oni koji ne mogu idu s kreveta, preko ograda i svašta..." (ISP7); »...Teško mi je kad u noćnu dođem i onda one su sve na nogama, sve, i onda ni jedna ne želi u krevet. Ova ide u školu, ova mora ići simtam, znate oni su u mladosti. Imamo jednu, nju u krevet dobit, ma kakvi...e tad mi dođe, ono stvarno teško, znoj ti curi dok se s njom boriš, teška je... " (ISP8); "...Ja dođem doma iz noćne, ja koja sam mlađa $i$ nemam doma ni djecu ni nikog cijeli dan sam nikakva, cijeli dan ne znam gdje sam, tek onaj drugi dan dođem $k$ sebi, a mogu mislit žene koje tu rade, koje imaju malu djecu... «(ISP6). Temeljem pregleda literature nije se posebno istaknuo problem zahtjevnosti rada u noćnoj smjeni. Međutim, znajući da je poremećaj sna koji spominju i Laklija i sur. (2009.) tipična karakteristika demencije, ovaj problem noćnih smjena dobiva svoje utemeljenje. Hoće li se kroz sustav omogućiti bolja organizacija rada te ukazati na specifične poteškoće u skrbi za ovu populaciju, ostaje pitanje. $U$ istraživanju Štambuk i sur. (2014.) socijalne radnice ukazuju na potrebu kategorizacije ustanova kao i izradu standarda u domovima za starije i nemoćne jer većina korisnika postaju upravo teško oboljele osobe, koje trebaju pojačanu njegu u odnosu na zdrave i neovisne korisnike.

Edukacije koje su ispitani njegovatelji prolazili usmjerile su im pažnju na individualizirani pristup oboljelim osobama koji je, nažalost, u uvjetima manjka osoblja i velikog broja korisnika nemoguće ostvariti: "...treba se više baviti s ljudima, više sadržaja uvesti, smatram da treba više radit individualno s njima, tako smo učili 
na edukaciji. Odnosno, dovoljno upoznati te ljude, to znači da ti trebaš biografiju njihovu znati, da bi se mogao posvetiti tom čovjeku i baviti se njime, a nažalost mi to još nemamo. "(ISP6); »...ona je na edukaciji pokazivala plan, u Švicarskoj je radila, bila je samo na odjelu s oboljelima od Alzheimerove demencije i onda je imala vremena normalno s njima individualno raditi, baš kako treba, a mi to nemamo, premalo nas je da bi se baš mogli posvetiti njima ..." (ISP7); "...znam da treba svakome individualno pristupat jer je to najbolje al nemamo za to vremena...«(ISP4). Individualizirani pristup »usmjeren na osobu « (eng. person-centred care) poželjan je oblik rada s osobama oboljelim od demencije. McKeown i sur. (2010.) ističu da detaljno poznavanje biografije korisnika, pozitivno utječe na uspostavljanje kvalitetnog odnosa, posebno iz razloga što za stručnjaka to nije više samo pacijent već osoba (eng. from patient to person). Karlsson i sur. (2014.) razmatrali su kako pisanje životne priče zajedno s njegovateljima utječe na oboljele te su zaključili kako je detaljno poznavanje životne priče zapravo ključ da bi se uopće mogao ostvariti pristup usmjeren osobi. Ovakav pristup pomaže oboljelome da što duže zadrži svijest o vlastitom identitetu. Na neki način se jača povezanost između prošlosti i sadašnjosti, kako navode Willis i sur. (2008.). Iz izjava njegovatelja može se prepoznati njihova osviještenost o dobrobitima individualiziranog pristupa, proizašla iz provedenih edukacija, što je još veći poticaj za unapređenje sustava kako bi se isto moglo realno provoditi u praksi.

3. Iscrpljenost je prepoznata kao sljedeći problem, a manifestira se kroz fizički napor, psihičku iscrpljenost i narušeno fizičko zdravlje.

Prema izjavama njegovatelja, oni svoj posao doživljavaju i kao fizički naporan što u kombinaciji s drugim faktorima do- vodi do iscrpljenosti: »...teški je to fizički posao..." (ISP7); »...fizički je jako naporno..." (ISP8); "...dizanje, okretanje, to je jako teško, okrenut nekog tko ima 20 kilograma i opušten je, teško je, a ovdje su svi puno teži..." (ISP11). Najveći fizički napor izražavaju njegovatelji oboljelih u posljednjoj fazi demencije kada više nisu pokretni te ih je potrebno i češće okretati u krevetu. Može se naslutiti da je fizičko preopterećenje povezano i s nedovoljnim brojem zaposlenika u odnosu na broj korisnika.

Psihička iscrpljenost spominje se kao sljedeći problem: »...nekad vas iscrpe, umore vas, to je normalno... Dođem kući $i$ moram se sat vremena odmorit... odležati i psihički se odmorit jer vas iscrpe..." (ISP3); "...imam osjećaj da sam psihički nakon nekog vremena, nakon nekoliko mjeseci slabiji. Kad dođete doma i kad se opustite imate osjećaj da ste psihički malo slabiji, iscrpljeni jer se potrošite tu s njima $i$ više se ne možete toliko fokusirati na obitelj..." (ISP13); »...nekad je stvarno psihički naporno, kad izađem osjećam kao da nisam bila dva dana vani jer mi smo tu zatvoreni s njima..." (ISP11). Kovačić Petrović i Repovečki (2016.) dolaze do rezultata da njegovatelji koji duži period rade s oboljelima od demencije, više verbaliziraju znakove psihičke iscrpljenosti. Hayajneh i Shehadeh (2014.) smanjenje osjećaja tereta i psihičke iscrpljenosti kod formalnih njegovatelja prepoznaju upravo u korištenju pristupa usmjerenog na osobu, što kako smo spomenuli ranije upućuje na bolju organizaciju rada, odnosno povećanje stručnog kadra.

Narušeno tjelesno zdravlje još je jedan od segmenata zbog kojih se njegovatelji osjećaju iscrpljeni poslom: "...vama neminovno odlazi i kičma i sve kompletno... meni je kičma, skroz otišla, puno se prije iscrpim sada..." (ISP6); "...teški je posao, leđa i sve po redu strada, teško je..." 
(ISP7); "...ja sad imam problema sa zdravljem pa onda više snage i energije moram uložiti, izmoždim se, umorno se osjećam..." (ISP9). Njega osoba s demencijom je zahtjevnija od njege samo fizički bolesnih starijih osoba te je lošije fizičko zdravlje neformalnih njegovatelja ove populacije povezano s više stresora u odnosu na ostale njegovatelje (Pinquart i Sörensen, 2003.).

Možemo zaključiti da se narušeno fizičko i psihičko zdravlje često spominju kao posljedice skrbi oboljelih od demencije kako kod formalnih tako i kod neformalnih njegovatelja.

4. Osjećaj bespomoćnosti sudionici istraživanja doživljavaju kroz teškoće u prepoznavanju potreba oboljelih, smanjeno osobno postignuće, teška i nerazumljiva ponašanja korisnika i nužnost davanja lijekova za smirenje.

Teškoće u prepoznavanju potreba oboljelih njegovatelji opisuju sljedećim rečenicama: "...Pa, najteže mi je kad je stvarno ono teški tip Alzheimera, stadij da ne znate kako jednostavno pomoć toj osobi, kad se rasplače, a vi ne znate što joj je, probate ovo, probate ono, jednostavno ne ide i ne ide..." (ISP3); "Željeli biste pomoći, a ne znate kako..." (ISP2); "...onda kad je ne možete nikako smirit, jer je ona konstantno u nekakvom grču $i$ vjerojatno ju nešto muči, a ne mogu shvatit što joj je...moram dati lijekove. "(ISP9). Nemogućnost odgovaranja na potrebe oboljelih vodi $\mathrm{k}$ osjećaju bespomoćnosti budući da često njegovatelji ne mogu adekvatno odgovoriti na potrebe oboljelih koji nisu u stanju verbalizirati što im je potrebno. Kitwood (1997.) navodi da i oboljeli od demencije mogu zadržati postojeću ili čak unaprijediti svoju razinu duhovnosti te da se smanjenjem kognitivnih sposobnosti povećava osjetljivost njihovih osjetila, emocija i duhovnosti. Mogućnosti su beskrajne: uključiti u ovaj proces i njima drage osobe (članove obitelji, prijatelje) opažati što je njima važno te se usuditi biti hrabar i kreativan. Pri tome se stručnjaci trebaju interesirati o vjerovanjima, vrijednostima i kreativnim sposobnostima svake pojedine osobe te poticati pozitivne emocije, usmjeravajući ih na njihove jake strane, na ono što još mogu napraviti.

Smanjeno osobno postignuće javlja se kad unatoč konstantnom ulaganju truda rezultati izostanu: »...Najteže mi je osobno što se trudiš $i$ daš sve od sebe, al' tu nema pomaka...Tu ne možeš očekivat napredak, da će se nešto poboljšat, samo ide nazad...i to je ono šta je deprimirajuće i frustrirajuće u svemu tome. Šta god da napraviš, koliko god da se trudimo sa svim mogućim aktivnostima, ali nema napretka, samo ono stagniranje i pad i to je ono žalosno u tome, ne možeš se nadati nekom ozdravljenju." (ISP8); "...Najteže mi je kad su u nekoj nervoznoj fazi, ... ako ju ne mogu riješiti, odnosno teško mi je zbog njih..." (ISP4); "Najgore je što daješ sve od sebe, koristiš edukacije, igre, kreativni rad, vrijeme, al' ne vidiš napredak, dapače čini ti se da ništa nisi postigao... « (ISP12). Družić Ljubotina i Friščić (2014.) u kontekstu sagorijevanja na poslu spominju upravo izraz smanjenog osobnog postignuća. Isti pojam pojašnjavaju s opadanjem osjećaja kompetencije i uspješnog postignuća u radu. Navedeno se čini usporedivo s odgovorima njegovatelja koji jasno iskazuju kako upravo taj izostanak napretka unatoč uloženom trudu može frustrirati. Sličnu situaciju spominju Burns i sur. (1996.; prema Laklija i sur., 2009.) koji su kod obiteljskih njegovatelja uočili doživljaj da ne dobivaju ništa za učinjeni trud. Snowden (2001: 195) navodi zanimljiv primjer starijeg gospodina s demencijom koji gotovo nije razgovarao. No, bio je vrlo razgovorljiv $s$ istraživačem koji ga je pitao kako se osjeća. Na kraju razgovora je rekao: »Ja ne govorim, jer me nitko ne sluša!« Važno je poznavati život osobe 
s kojom razgovaramo, pokazati strpljenje i ne prekidati u razgovoru te odvojiti dovoljno vremena za uspostavljanje odnosa povjerenja.

Sljedeće što formalni njegovatelji navode su teška i nerazumljiva ponašanja korisnika: »...Oni znaju biti $i$ agresivni, $i$ šta ćeš onda..." (ISP7); "Ima ih svakakvih, koji su čangrizavi i agresivni, u početku su $u$ redu, ali s vremenom je ponašanje sve teže..." (ISP5); »... gledam sto puta jedno te isto, još kod nas su pokretni svi ti Alzheimeri $i$ oni se i među sobom prepiru, svađaju, teško je svaki dan gledati takvo ponašanje..." (ISP1). Skrb za osobe smještene u domove za starije i nemoćne podrazumijeva prema Rusac (2011.) uvažavanje osobnih razlika, osobnog dostojanstva i individualnosti svake osobe. U slučaju demencije, ponekad postaje teško razgraničiti što dolazi od ličnosti same osobe, a što je rezultat pojave bolesti koja može dovesti do ponašanja koja su u potpunom nesuglasju s karakterom osobe. U istraživanju Isaksson i sur. (2012.) nalazi su pokazali da ne postoji najučinkovitiji način rješavanja situacija obilježenih agresivnošću, već je potrebna velika fleksibilnost, odnosno prilagodba reakcije ovisno o situaciji. U konačnici, svakodnevna izloženost takvim situacijama u kojima se teško pronalaze učinkovite metode rješavanja problema može voditi k tome da se stručnjaci osjećaju bespomoćno.

Kao krajnji potez koji poduzimaju, njegovatelji navode situacije u kojima je nužno dati lijekove za smirenje: "Recimo, kad ih ne mogu smiriti, kad im moram dati lijekove za smirenje, to mi je onako najteže... recimo, jedna gospođa zna i po noći vikati i svašta zna s njom biti. Onda kad je ne uspijemo smiriti moramo lijekove dati." (ISP9); "Kad ne vidimo kako smirit situaciju, onda damo lijekove, nemaš izbora, a to meni bude jako teško..." (ISP2); »... a i kad je jako nemirna, posebno po noći pa budi ostale, šta ćeš nego joj dati lijek..." (ISP10). Pitanje korištenja lijekova za smirenje nije često spominjano u literaturi. Ipak, vrlo je važno da senzibilizacija i edukacija stručnjaka upućuje na profesionalnu odgovornost i etičnost pri poduzimanju takvih radnji. Mimica (2011.) stavlja naglasak kako je prije posezanja za farmakološkim tretmanom, potrebno primijeniti nefarmakološke intervencije prema individualnoj procjeni. Upravo ta procjena može predstavljati teret stručnjacima, ali također je i pokazatelj njihove etičnosti i (ne)educiranosti u radu.

\section{Dobrobiti rada u skrbi za osobe oboljele od demencije}

Dobrobiti koje formalni njegovatelji prepoznaju u skrbi za osobe oboljele od demencije, prikazane su kroz četiri teme koje predstavljaju odgovor na drugo istraživačko pitanje. Radi preglednijeg prikaza rezultata sve su teme i podteme ilustrirane u tablici 2. 
Tablica 2.

Dobrobiti rada u skrbi za osobe oboljele od demencije

Tematsko područje: Dobrobiti rada u skrbi za osobe oboljele od demencije

Teme Podteme

1. Osjećaj ispunjenosti

1. Emocionalno ispunjenje

2. Osjećaj zadovoljstva

3. Razvijanje bliskosti

2. Povećani osjećaj smisla i životne svrhe
1. Doživljaj posla kao »poziva«

2. Produbljivanje osjećaja odgovornosti za druge.

3. Učiti »biti zadovoljan onime što imaš«

1. Osjećaj postignuća i kompetentnosti

2. Učenje timskog rada

3. Profesionalna edukacija

4. Razvijanje pozitivnih osobina
3. Osobni rast

4. Novi pogled na osobe starije životne dobi
1. Učenje od oboljelih

2. Nestajanje predrasuda o osobama starije životne dobi
1. Emocionalno ispunjenje je važna dobrobit za njegovatelje, a proizlazi iz: osjećaja ispunjenosti, osjećaja zadovoljstva i razvijanja bliskosti s oboljelim osobama.

Osjećaj ispunjenosti možemo vidjeti u sljedećim izjavama: »Pa, ja se osobno osjećam jako ispunjeno, zato jer to volim...." (ISP1); "...nekako sam ispunjena samim tim jer pomažem. To i radim deset godina i jednostavno dobro je... ne vidim se negdje drugdje. "(ISP2); "... ja se osjećam dobro, ispunjeno..." ( ISP8). Osjećaj ispunjenosti spominju Brodaty i Donkin (2009.) u istraživanju o članovima obitelji uslijed preuzimanja skrbi za oboljelog člana. Ipak, gore navedene izjave ispitanika neminovno potvrđuju da se on javlja i kod formalnih njegovatelja bez obzira na nepostojanje rodbinske veze, što možemo objasniti svakodnevnom i dugotrajnom skrbi i uspostavom bliskih odnosa, ali i specifičnom teškom bolešću korisnika koji pati. Osjećaj da su umanjili bilo koju vrstu patnje donosi njegovateljima zadovoljstvo.
Uz ispunjenost je vezan i osjećaj zadovoljstva: "... Osjećam se zadovoljno radeći taj posao..." (ISP14); "...meni je tu odlično i zadovoljna sam poslom...." (ISP13). Zadovoljstvo poslom često je predmet istraživanja zbog uvriježenog mišljenja kako uvelike utječe na produktivnost radnika. U prethodnom je dijelu bilo spomenuto kako postignuće često izostaje zbog naravi same bolesti. Ipak, osjećaj zadovoljstva koji njegovatelji verbaliziraju ukazuje da, unatoč teškoćama u pružanju skrbi, vide smisao svog rada, što je kasnije opisano. Zanimljiv je pristup Zimmermana i sur. (2005.) koji osjećaj zadovoljstva kod formalnih njegovatelja povezuju s prakticiranjem pristupa usmjerenog na osobu. Naime, autori su došli do zaključka da su njegovatelji koji koriste navedeni pristup i zadovoljniji poslom.

Razvijanje bliskosti s korisnicima također ukazuje na emocionalnu ispunjenost koju njegovatelji doživljavaju: »Doživjela sam puno toga lijepog, kao prvo upozna- 
la sam sve te drage ljude i njihove obitelji koji, nažalost, imaju dijagnozu te teške bolesti, prirasli su mi srcu..." (ISP1); »Jako ih volim i meni je s njima lijepo, čovjek se s njima zbliži, čovjek s njima svašta doživi, prolazite kroz njihove tuge i njihova neraspoloženja, kroz njihovu euforiju i duhovite situacije." (ISP3); »... pokažu ti nekako da ste tu negdje povezani..." (ISP5). Brodaty i Donkin (2009.) spominju kako pružanje skrbi obiteljskim njegovateljima daje jedinstveni osjećaj zajedništva i povezanosti s oboljelima, a rezultati ovog istraživanja ukazuju da se to može proširiti i na formalne njegovatelje. Uzimajući u obzir da određeni broj oboljelih i više godina boravi u instituciji, kao i da neki njegovatelji imaju puno godina radnog staža (neki i 30!), razvijanje osjećaja bliskosti kroz međusobno upoznavanje je neminovno te na neki način doprinosi olakšanju u obavljanju posla.

\section{Povećani osjećaj smisla i životne} svrhe njegovatelji pronalaze i zbog toga što svoj posao doživljavaju kao »poziv«, produbljuju osjećaj odgovornosti za druge i uče biti zadovoljni onim što imaju.

Doživljavanje posla kao "poziva" njegovatelji opisuju sljedećim izjavama: "\#... lijepo mi je s njima, volim ih, kako da to objasnim, baš su mi super, našao sam se u tom poslu...to je zapravo više od posla... kao poziv..." (ISP14); "...i jednostavno da biste tu mogli raditi morate $i$ voljeti to. To je puno više od zarađivanja za život..." (ISP2); "...Pa meni je jako lijep taj posao, puno ljepši nego bilo koji drugi.« (ISP 15). Istraživanje Butcher i sur. (2001., prema Laklija i sur., 2009.) ističe kako se kod njegovatelja doživljeno iskustvo pružanja skrbi percipira kao povećani osjećaj smisla i životne svrhe što u globalu utječe na zadržavanje pozitivnih osjećaja prema primatelju skrbi. Gornje izjave ukazuju na to da formalni njegovatelji posao ne doživljavaju mehanički, nego mu daju jednu drugu, du- blju dimenziju - vole ga i doživljavaju ga kao poziv.

Značajan broj ispitanika ističe da ovaj posao utječe na produbljivanje osjećaja odgovornosti za druge: "... mogu reći da nadograđuješ tu svoju odgovornost, to je odgovoran posao, više pažnje pridaješ drugim osobama, ne samo dementnima, kao da na neki način utječe $i$ općenito na druge odnose, upravo tako..." (ISP15); ».. ja sam i oduvijek tako odgovorna, a ovo me je u tome učvrstilo." (ISP12); "... općenito prema drugim ljudima postaneš više odgovoran..." (ISP9). Neki su od ispitanika spominjali da njihova zanimanja (njegovatelji, medicinske sestre) iziskuju veliku odgovornost bez koje ne bi mogli raditi posao u struci, no naglašavaju kako je ipak rad s osobama oboljelim od demencije doprinosi produbljivanju te odgovornosti. Istraživanje Butcher i sur. (2001., prema Laklija i sur., 2009.) imalo je u fokusu obiteljske njegovatelje, no razvijanje odgovornosti za druge također je prepoznato kao dobrobit.

Današnji ubrzani način života u kojem

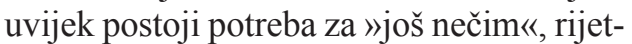
ko ostavlja prostora da čovjek postane svjestan onoga što ima, odnosno puno je više usmjeren na ono što nema. Odgovori formalnih njegovatelja pokazuju kako upravo posao koji rade pruža mogućnost učenja da budu zadovoljni onime što imaju: "... shvatiš da možeš biti zadovoljan svime što imaš, može netko od mojih postati bolestan, mi ljudi često zaboravljamo na to..." ( ISP12); "...kroz to sve sam možda počela cijeniti svoje zdravlje $i$ zdravlje svojih najbližih, znači to nas osvijesti da sutra tu mogu biti ja..." (ISP1); "... kad sam u druženju s prijateljima ne znam kako su ljudi danas nezadovoljni s ovim s onim, svi teže ka nečem višem. Probam im približit kako je taj život kratak i kako ga treba živjet punim plućima jer nitko ne zna što ga sutra čeka.«(ISP2). Navedeni odgovori ukazuju 
da formalni njegovatelji kao osobnu dobrobit prepoznaju upravo to da ih je bolest $\mathrm{s}$ kojom se u radu suočavaju osvijestila što im sve može biti oduzeto pojavom bolesti, a praktički se podrazumijeva »normalnim« i uobičajenim u svakodnevnom životu. Takvo se mišljenje može tumačiti i pomoću činjenice da je demencija bolest kojoj se ne može sa sigurnošću utvrditi uzrok (Kovačić Petrović i Repovečki, 2016.), što objašnjava ovaj stav njegovatelja da nitko nije siguran da upravo on neće oboljeti od iste bolesti i to u njima »rađa« osjećaj zadovoljstva i zahvalnosti za ono što imaju. Treba spomenuti kako novija istraživanja o psihosocijalnim faktorima kao mogućim rizicima za nastanak demencije uključuju: depresiju, manjak pozitivnih emocija, manjak smisla u životu, psihološki stres, manjak socijalne uključenosti te manjak savjesnosti i visoki stupanj neuroticizma (Koening, King i Carson, 2012.).

3. Osobni rast kao dobrobit uključuje: osjećaj postignuća i kompetentnosti, učenje timskog rada, profesionalnu edukaciju i razvijanje pozitivnih osobina.

Osjećaj postignuća i kompetentnosti njegovatelji su iskazali u sljedećim izjavama: "...ova gospođa koja je sad bila tu, kada je došla nije znala složit rečenicu, a sada možemo s njom komunicirat puno bolje, za njen napredak smo i mi zaslužni jer dosta komuniciramo s njom, na neki način osjećaš se sposobnim..." (ISP11); »... pa svaki dan je nešto lijepo zato što oni kroz svoju demenciju i bolest, vas prepoznaju i nekakvom gestom vam daju do znanja da dobro radite, da ste im dragi... zagrljaj, osmjeh .... takve nekakve sitne geste su najveća nagrada..." (ISP4); »... lijepo mi je kad se nasmiju, kad vidim da su smireni, da se nečemu razvesele, neki stalno ponavljaju iste fraze, al' kad krene tu jednu frazu sto puta ponavljat kroz smiješak onda znam da su sretni - gdje, s kim, u kojoj priči, uopće nije bitno..." (ISP2). Osjećaj postignuća i kompetentnosti javlja se čak i kod minimalnog napretka oboljelih (Brodaty i Donkin, 2009.). Zanimljivo je spomenuti, kako je osjećaj postignuća bio oprečno spomenut u prvom dijelu rada kad su isti njegovatelji kao problem navodili izostanak osobnog postignuća kod nekih korisnika. Može se zaključiti kako i jedan i drugi kontekst uvelike čine važan izazov u radu s oboljelima. S jedne strane, kao što je ranije spomenuto, to može biti frustrirajuće, ali s druge strane mali pomaci mogu njegovateljima biti kako sami kažu, »najveća nagrada « i razlog zbog kojeg ustraju i uživaju u poslu. Zimmerman i sur. (2005.) na zanimljiv način iznose kako je osjećaj postignuća i kompetentnosti povezan i s pristupom usmjerenim na osobu na način da oni njegovatelji koji ga koriste postižu veći osjećaj kompetentnosti i postignuća.

Pozitivni učinci multidisciplinarnog pristupa prepoznati su i od strane formalnih njegovatelja koji dobrobit vide i u učenju timskog rada kroz obavljanje skrbi: »... stvarno ove osobe zahtijevaju strpljenje $i$ razumijevanje $i$ onda se u timu međusobno nadopunjujemo što puno pomaže. " (ISP8); »Da, timski rad je kod nas moram priznat dobro razvijen - učimo se zajedno funkcionirati, sestre i njegovatelji... Na kraju priče i spremačice 'uskaču' kad njima stalno nešto treba pobrisati, posložiti, pospremiti..." (ISP5); »...jedna drugoj se izjadamo i onda je lakše...i onda opet danas je gore, sutra je bolje, ali kad naučiš dijelit $s$ nekim iz tima, onda je sve manje stresno..." (ISP7). Zadelhoff i sur. (2011.) također ističu važnost timskog rada u skrbi za osobe $\mathrm{s}$ demencijom. Družić Ljubotina i Friščić (2014.) govore kako timski rad omogućuje stjecanje novih znanja te može pridonositi zadovoljstvu u radu.

Za kvalitetno obavljanje skrbi prepoznata je važnost profesionalne edukacije: 
"Pomaže mi to šta smo mi svi prošli tečaj integrativne validacije i bazalne stimulacije." (ISP3); "Meni je tu super, imam priliku učiti nove stvari, prošli smo validaciju, sad prolazimo ove tečajeve za opuštanje..." (ISP13); "Prošla sam par edukacija koje su bile toliko kvalitetne da drugo ništa nisam čula, to bi mi bilo dovoljno. "(ISP5). U prethodnom dijelu spominjala se edukacija u kontekstu nedostatnosti znanja o bolesti od strane članova obitelji. Zanimljivo je primijetiti kako formalni njegovatelji često spominju konkretne edukacije (integrativna validacija, bazalna stimulacija, soba za opuštanje) koje su prošli i njihovu primjenu u svakodnevnom radu. Iz odgovora se može naslutiti kako iste edukacije smatraju korisnima i upotrebljivima. I neka su druga istraživanja upućivala na važnost edukacija za rad s oboljelima od demencije (Štambuk i sur., 2014.). Stoga se možemo nadati njihovu nastavku i pospješivanju u budućnosti u kojoj se očekuje porast broja oboljelih od demencije. Pitanje kojeg su se dotakli i neki ispitanici ide u smjeru toga jesu li u svim institucijama stručnjaci toliko educirani o bolesti ili ipak ima slučajeva da skrb obavljaju nekvalificirane osobe ili pak oni koji ispunjavaju obvezu javnih radova, što su sami formalni njegovatelji s neodobravanjem spomenuli kroz ovo istraživanje.

Skrb za oboljele od demencije omogućava razvijanje pozitivnih osobina koje utječu i na život njegovatelja izvan radnog mjesta: »Čovjek se u tom poslu uči velikom strpljenju i razumijevanju, mora bit strpljiv $i$ tolerantan $i$ onda se to odražava na sve $u$ životu, na privatni život, na obaveze, aktivnosti, ukućane, djecu, odnose s prijateljima..." (ISP8); "... više pažnje pridaješ drugim osobama, ne samo dementnima, na drugi način opet gledaš druge ljude, $s$ više razumijevanja..." (ISP15); "Postala sam puno empatičnija i toplija, baš zato jer $i$ nesvjesno razvijemo taj osjećaj empatije što je jako bitno, znači da se ne radi ništa automatski, rutinski $i$ onda to prenosiš $i$ u odnosu prema drugim ljudima..." (ISP1). Obrazovanje za pomažuće profesije trebalo bi uključivati i učenje o važnosti osobina poput empatije, uvažavanja, razumijevanja drugih itd. Ovdje vidimo kako rad u praksi konkretno pomaže pri usvajanju takvih vještina. Isto je prepoznato $u$ istraživanju Mitrani i Czaja (2000.) gdje njegovatelji smatraju da kroz skrb razvijaju pozitivne osobine što doprinosi njihovom osobnom rastu.

4. Zanimljivo je da $\mathrm{rad} \mathrm{s}$ osobama $\mathrm{s}$ demencijom donosi i novi pogled na osobe starije životne dobi, koji njegovatelji stječu kroz učenje od oboljelih i nestajanje predrasuda o osobama starije životne dobi.

Unatoč teškoj dijagnozi, njegovatelji prepoznaju mogućnost učenja od oboljelih osoba: "... učiš nešto novo, učiš od njih..." (ISP6); "...shvatiš da itekako imaš puno za učit od njih, ipak je to bogato životno iskustvo koje oni imaju, čak $i$ kad više nisu svega svjesni..." (ISP4); "...nije da samo oni uče od tebe, baš suprotno, vidiš njihov život i možeš učit iz njega..." (ISP2). Ranije je spomenuto istraživanje Mckeown i sur. (2010.) koji između ostalog ističu da kroz pregled života oboljele osobe formalni njegovatelji pronalaze priliku za učenje. Istraživanja o obiteljskim njegovateljima osoba s demencijom također donose pozitivne učinke skrbi. Tako Sorrell (2005., 2006.) u svojim istraživanjima govori o sreći i unapređenju kvalitete života kod njegovatelja osoba s demencijom, unatoč fizičkoj i psihičkoj iscrpljenosti.

Novi pogled na osobe starije životne dobi dolazi i kroz nestajanja predrasu$\boldsymbol{d a}$ koje su njegovatelji imali prije rada na ovom području: »Pa možda gledanje općenito na starije osobe sa takvim potrebama, bolestima, ne mora sad samo biti Alzheimer, ...ipak mislim da imam više razumije- 
vanja prema njima... «(ISP 5); »... općenito na starije ljude drugačije gledam, s više razumijevanja i bez nekih pretpostavki od prije...« (ISP 5);»Primijetila sam da ima puno predrasuda. Kad sam bila u pratnji s gospođom u bolnici, ima ljudi koji su prolazili pokraj nje, svi se čude, svi se zgražaju. Al i ja sam bila takva prije, meni je zapravo posao pomogao da uništim te predrasude." (ISP9). Mnoga istraživanja ističu važnost neposrednog iskustva, ali i socijalnog utjecaja $\mathrm{u}$ promjeni stavova prema starijima (Lee, Reuben i Ferrell, 2005.; Scheffer, 1995.; prema Štambuk i sur., 2011.). Nameće se pitanje na kome leži odgovornost da se starija dob počinje predstavljati kao izvor mudrosti i iskustva umjesto da se mlađoj populaciji serviraju samo negativni aspekti koje starost, ali i svako životno razdoblje neminovno donosi? Prije svega, treba educirati stručnjake svih profesija koji pomažu u skrbi za oboljele o posljedicama demencije na ličnost bolesnika, obitelj i zajednicu, kao i strategijama suočavanja sa stresom, specifičnostima komunikacije i pristupa. Kroz različite medije može se educirati i širu društvenu javnost ističući upravo pozitivne učinke skrbi te na taj način doprinijeti destigmatizaciji oboljelih koji se često gledaju kao osobe od kojih se više nema što naučiti i koji su teret svima. Također, i kroz prihvaćanje demencije kao nove bolesti osoba treće životne dobi mladim ljudima omogućujemo veću senzibiliziranost za njih (Mimica, 2011.).

\section{ZAKLJUČNA RAZMATRANJA}

Cilj ovog istraživanja bio je dobiti uvid u poteškoće i dobrobiti rada s osobama oboljelim od demencije iz perspektive formalnih njegovatelja. Temeljem provedene analize podataka probleme koje navode formalni njegovatelji možemo razgraničiti na one koje se tiču njih samih (osjećaj bespomoćnosti i iscrpljenost), zatim one veza- ne uz organizaciju posla (manjak osoblja, zahtjevnost rada u noćnim smjenama, nemogućnost individualiziranog pristupa) te nerazumijevanje od strane članova obitelji (slaba educiranost o bolesti, neprihvaćanje i teška prilagodba na progresiju bolesti, nerealni zahtjevi i nepovjerenje prema stručnim djelatnicima). Sve navedeno ukazuje na činjenicu da profesionalna skrb o oboljelima od demencije iziskuje visoke zahtjeve s kojima se formalni njegovatelji suočavaju, a stručne podrške, odnosno supervizije za njih nema. Važno je u budućnosti ustrajati na edukaciji za obitelj, zaposliti više stručnog osoblja kako bi se mogao primijeniti individualni pristup oboljelima, ali isto tako zaštititi stručne djelatnike od sagorijevanja na poslu kroz uvođenje supervizije. Odgovornost zagovaranja formalnih njegovatelja leži na svima koji bilo u istraživačkom ili praktičnom radu, imaju prilike uvidjeti složenost i zahtjevnost skrbi. U konačnici, nazire se potreba za razvijanjem suportivnih programa, kako za članove obitelji tako i za profesionalne njegovatelje kao i veću prisutnost volontera u ovim institucijama.

Drugim istraživačkim pitanjem nastojalo se saznati koje dobrobiti njegovatelji uočavaju kroz skrb za oboljele. Široku lepezu odgovora svrstali smo u četiri teme: emocionalno ispunjenje, povećani osjećaj smisla i životne svrhe, osobni rast te novi pogled na osobe starije životne dobi. Iako su dobrobiti pružanja skrbi ovoj populaciji rjeđi predmet interesa $u$ istraživačkoj literaturi, spoznaje o njima mogu ukazivati na neke zaštitne čimbenike koji stručnjacima pomažu da se nose s problemima koje skrb pred njih stavlja. Upravo je u tome doprinos $\mathrm{i}$ ovog istraživanja.

Na kraju ćemo spomenuti i ograničenja provedenog istraživanja. Jedno od njih je nepostavljanje kriterija minimalnog staža njegovatelja u skrbi za oboljele od demen- 
cije što je rezultiralo puno oskudnijim odgovorima ispitanika koji su manje od godine dana zaposleni na ovom području te se daje naslutiti kako je iskustvo važan faktor za ovakav tip istraživanja, o čemu treba voditi računa u budućim istraživanjima. Bilo bi zanimljivo longitudinalnim istraživanjem pratiti promjene u njegovateljskom radu što bi moglo pomoći u pružanju podrške istima u budućnosti. Također, bilo bi dobro napraviti istraživanje koje nije ograničeno samo na područje grada Zagreba.

Možemo zaključiti da dobiveni rezultati mogu poslužiti kao smjernice za promišljanja u budućim istraživanjima o formalnim, ali i neformalnim njegovateljima osoba $\mathrm{s}$ demencijom kao i boljoj organizaciji rada u ustanovama koje skrbe o starijim osobama. Čini se kako je potrebna i izrada profesionalnih standarda u radu s osobama s demencijom, bolja informiranost obitelji i šire društvene javnosti o posljedicama bolesti i specifičnostima skrbi kao i dobrobitima koje se rijetko ističu. Humanost jednog društva može se mjeriti jedino brigom za najosjetljivije članove, a osobe s demencijom kao i oni koji o njima brinu svakako to zaslužuju i kroz naš profesionalni angažman.

\section{LITERATURA}

Alzheimer's Disease International. (2015). World Alzheimer Report 2015. The global impact of dementia - An analysis of prevalence, incidence, cost and trends. Available at https:// www.alz.co.uk/research/WorldAlzheimerReport2015.pdf

Braun, V., \& Clarke, V. (2006). Using thematic analysis in psychology. Qualitative research in Psychology, 3(2), 77-101. https://doi. org/10.1191/1478088706qp063oa

Brodaty, H., \& Donkin, M. (2009). Family caregivers of people with dementia. Dialogues in Clinical Neurosciences, 11(2), 217-228. https:// www.ncbi.nlm.nih.gov/pubmed/19585957
Colello, K. J. (2009). Family caregiving to the older population: Background, federal programs and issues for Congress. Congressional Research Service. Available at http://www. aging.senate.gov/crs/aging 10.pdf

Diminić-Lisica, I., \& Rončević-Gržeta, I. (2010). Obitelj i kronična bolest. Medicina fluminensis, 46(3), 300-308. https://hrcak.srce. $\mathrm{hr} / 59255$

Dröes, R.-M., Breebaart, E., Meiland, F. J. M., Van Tilburg, W., \& Mellenbergh, J. (2004). Effect of meeting centres support program on feelings of competence of family carers and delay of institutionalization of people with dementia. Aging \& Mental Health, 8(3), 201-211. https:// doi.org/10.1080/13607860410001669732

Družić Ljubotina, O., \& Friščić, Lj. (2014). Profesionalni stres kod socijalnih radnika: Izvori stresa i sagorijevanje na poslu. Ljetopis socijalnog rada, 21(1), 5-32. https://doi. org/10.3935/ljsr.v21i1.10

Državni zavod za statistiku. (2016). Stanovništvo prema starosti i spolu, popisi 1953-2011. Dostupno na http://www.dzs.hr/Hrv/censuses/ census2011/ censuslogo.htm

Elo, S., \& Kyngas, H. (2008). The qualitative content analysis process. Journal of Advanced $\mathrm{Nu}$ rsing, 61(1), 107-115. https://doi.org/10.1111/ j.1365-2648.2007.04569.x

Folnegović-Šmalc, V., Uzun, S., Kozumplik, O., Folnegović-Grošić, P., Henigsberg, N., Makarić, G., Mihanović, M., \& Mimica, N. (2002). Farmakoterapija Alzheimerove bolesti. $\mathrm{Me}$ dicus, 11(2), 217-222. https://hrcak.srce. $\mathrm{hr} / 19974$

Hayajneh, F. A., \& Shehadeh, A. (2014). The impact of adopting person-centred care approach for people with Alzheimer's on professional caregivers' burden: An interventional study. International Journal of Nursing Practice, 20(4), 438-445. https://doi.org/10.1111/ ijn.12251

Isaksson, U., Astrom, S., \& Graneheim, U. (2012). Being flexible and tuning in: Professional caregivers' reflections on management of violent behaviour in nursing homes. International Journal of Older People Nursing, 8(4), 290298. https://doi.org/10.1111/opn.12005 
Jedvaj, S., Štambuk, A., \& Rusac, S. (2014). Demografsko starenje stanovništva i skrb za starije osobe u Hrvatskoj. Socijalne teme, 1(1), 135-154. https://hrcak.srce.hr/177570

Karlsson, E., Savenstedt, S., Axelsson, K., \& Zingmark, K. (2014). Stories about life narrated by people with Alzheimer's disease. Journal of Advanced Nursing, 70(12), 2791-2799. https://doi.org/10.1111/jan.12429

Kitwood, T. (1997). Dementia reconsidered: The person comes first. Buckingham: Open University Press.

Koening, H. G., King, D. E., \& Carson, V. B. (2012). Handbook of religion and health (2nd ed.). Oxford: Oxford University Press.

Kovačić Petrović, Z., \& Repovečki, S. (2016). Učestalost anksioznih i depresivnih simptoma kod obiteljskih i profesionalnih njegovatelja koji skrbe o oboljelima od Alzheimerove bolesti. Socijalna psihijatrija, 44(2), 93-104. https://hrcak.srce.hr/162822

Laklija, M., Milić Babić, M., \& Rusac, S. (2009). Neki aspekti skrbi o članu obitelji oboljelom od Alzheimerove bolesti. Ljetopis socijalnog rada, 16(1), 69-89. https://hrcak.srce.hr/35433

Levkoff, S., Levy, B., \& Flyn Weitzman, P. (1999). The role of religion and ethnicity in the help seeking of family caregivers of elders with Alzheimer's disease and related disorders. Journal of Cross-Cultural Gerontology, 14(4), 335-356. https://doi. org/10.1023/A:1006655217810

Li, H. (2002). Family preferences in caring for their hospitalized elderly relatives. Geriatric $\mathrm{Nu}$ rsing, 23(4), 204-207. https://doi.org/10.1067/ mgn.2002.126966

McKeown, J., Clarke, A., Ingleton, C., Ryan, T., \& Repper, J. (2010). The use of life story work with people with dementia to enhance personcentred care. International Journal of Older People Nursing 5(2), 148-158. https://doi. org/10.1111/j.1748-3743.2010.00219.x

Milić Babić, M., Laklija, M., \& Rusac, S. (2014). Neke odrednice zadovoljstva socijalnom podrškom njegovatelja osoba oboljelih od Alzheimerove bolesti. Revija za socijalnu politiku, 21(2), 201-218. https://doi.org/10.3935/rsp. v21i2. 1180
Mimica, N. (2011). Demencija i palijativna skrb. Neurologia Croatica, 60(3-4), 119-123.

Mimica, N., \& Presečki P. (2010). Current treatment options for people with Alzheimer's disease in Croatia. Chemico-Biological Interactions, 187(1-3), 409-410. https://doi. org/10.1016/j.cbi.2010.03.029

Mitrani, V. B., \& Czaja, S. J. (2000). Family-based therapy for dementia caregivers: Clinical observations. Aging \& Mental health, 4(3), 200209. https://doi.org/10.1080/713649924

Naylor, M. D., Stephens, C., Bowles, K. H., \& Bixby, M. B. (2005). Cognitively impaired older adults: From hospital to home. American Journal of Nursing, 105(2), 52-61. https://doi. org/10.1097/00000446-200502000-00028

Nichols, J. N. (2006). Windows to the heart: Creating an acute care dementia unit. In N. M. Silverstein \& K. Maslow (Eds.), Improving hospital care for people with dementia. New York: Springer.

Parker, J., \& Penhale, B. (1998). Forgotten people: Positive approaches to dementia care. Aldershot: Ashgate.

Perko, G., Tomek-Roksandić, S., Mihok, D., Puljak, A., Radašević, H., Tomić, B., \& Čulig, J. (2005). Četiri javnozdravstvena problema u zaštiti zdravlja starijih osoba u Hrvatskoj. Medicus, 14(2), 205-217. https://hrcak.srce. $\mathrm{hr} / 18874$

Pinquart, M., \& Sörensen, S. (2003). Differences between caregivers and noncaregivers in psychological health and physical health: A meta-analysis. Psychology and Aging, 18(2), 250-267. https://doi.org/10.1037/08827974.18.2.250

Poredoš, D. (2003). Alzheimerova bolest i obitelj. Ljetopis socijalnog rada, 10(2), 243-254. https://hrcak.srce.hr/3515

Robbins, S. P. (1992). Bitni elementi organizacijskog ponašanja. Zagreb: MATE.

Rusac, S. (2011). Motivacija za supervizijom socijalnih radnika u domovima za stare I nemoćne. Ljetopis socijalnog rada, 18(2), 305-331. https://hrcak.srce.hr/74091

Rusac, S., Laklija, M., \& Milić Babić, M. (2012). Strategije suočavanja članova obitelji oboljelih od Alzheimerove bolesti. Hrvatska revija 
za rehabilitacijska istraživanja, 48(2), 87-96. https://hrcak.srce.hr/87796

Schoenmakers, B., Buntinx, F., \& DeLepeleire, J. (2010). Supporting the dementia family caregiver: The effect of home care intervention on general well-being. Aging \& Mental Health, 14(1), 44-56. https://doi. org/10.1080/13607860902845533

Snowden, D. (2001). Ageing with grace. London: HarperCollins.

Sorrell, J. M. (2005). Struggling to do the right thing: Stories from people living with Alzheimer's disease. Journal of Psychosocial Nursing and Mental Health Services, 43(7), 13-16. https://doi.org/10.3928/0279369520100528-01

Sorrell, J. M. (2006). Listening in thin places: Ethics in the care of persons with Alzheimer's disease. Advances in Nursing Science, 29(2), 152-160. https://doi.org/10.1097/00012272200604000-00008

Štambuk, A., Leutar, Z., \& Žitnik, M. (2011). Stavovi građana prema starijim osobama. U M. Buljevac, I. Leutar, A. Štambuk, B. W. Shank \& Z. Leutar (ur.), Zbornik radova Međunarodne znanstvene konferencije "Soci- jalni rad i borba protiv siromaštva i socijalne isključenosti - profesionalna usmjerenost zaštiti i promicanju ljudskih prava" (str. 225244). Zagreb: Zaklada Marija de Mattias.

Štambuk, A., Sučić, M., \& Vrh, S. (2014). Socijalni rad u domu za starije i nemoćne osobe: izazovi i poteškoće. Revija za socijalnu politiku, 21(2), 185-200. https://doi.org/10.3935/ rsp.v21i2.1182

Wills, T., \& Day, M. R. (2008). Valuing the person's story: Use of life story books in a continuing care setting. Clinical Interventions in Aging, 3(3), 547-552. https://doi.org/10.2147/ CIA.S1620

Zadelhoff, W., Verbeek, H., Widdershoven, G., Rossum, E. \& Abma, T. (2011). Good care in group home living for people with dementia. Experiences of residents, family and nursing staff. Journal of Clinical Nursing, 20, 24902500.

Zimmerman, S., Williams, C.S., Reed, P.S., Boustani, M., Preisser., J.S., Heck, E. \& Sloane, P.D. (2005). Attitudes, Stress, and Satisfaction of Staff Who Care for Residents With Dementia. The Gerontologist, 45(1), 96-105. 


\title{
Summary
}

\section{THE DIFFICULTIES AND BENEFITS OF WORKING WITH PEOPLE WITH DEMENTIA FROM THE PERSPECTIVE OF FORMAL CAREGIVERS}

\author{
Ana Štambuk \\ Department of Social Work, Faculty of Law, University of Zagreb \\ Zagreb, Croatia
}

\section{Kristina Levak}

Inability to self-care in old age is often caused by various diseases. Caring for a person with dementia has been described as the most demanding form of care due to its intensity and duration. Given that currently about 47 million people suffer from this disease, the expansion of which is still expected, it can be said that dementia has a great economic impact on society as well. Due to the demands of everyday life, modern families are no longer able to adequately take care of their members, which has increased the need for formal care settings. Professional or formal caregivers are experts of different professions who daily face many challenges in custody relationships. The aim of this study was to gain an insight into the difficulties and the benefits of working with people with dementia from the perspective of formal caregivers. The qualitative study involved 15 caregivers from 4 different institutions in Zagreb with whom semi-structured interviews were conducted. The results of thematic analysis of the data showed that caregivers identified two operational problems: the lack of understanding by family members and poor organization of work. Besides, their work leads them to exhaustion and feeling of helplessness. With regard to the benefits, the results show that in addition to emotional fulfillment and an increased sense of meaning and purpose of life, caregivers perceived a personal growth and a new perspective on the elderly they gain as benefits too. In conclusion, the study shows that further systematic research on caregivers is needed in order to obtain guidelines for developing the system, which in Croatia can still be characterized as a quite inadequate one with regard to existing needs.

Keywords: elderly, formal caregivers, dementia, care. 